\title{
GEOLOGIC AND AEROMAGNETIC MAP OF NORTHERN MAINE
}

\author{
By \\ Arthur J. Boucot, Andrew Griscom, and John W. Allingham
}

GEOPHYSICAL INVESTIGATIONS

MAP GP-312

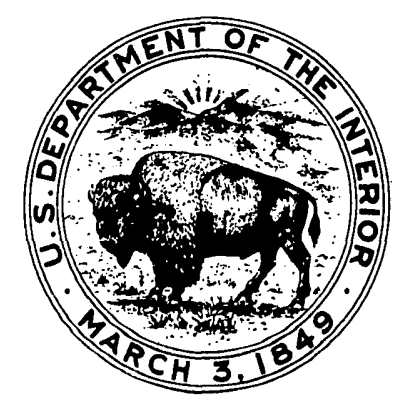




\section{GEOLOGY}

By

Arthur J. Boucot and Andrew Griscom

\section{Introduction}

Information for the present compilation has been derived from two main sources:

(1) Geologists who have recently done or are now doing geologic mapping in northern Maine (see index map showing sources of geologic information). This information is reliable and reasonably detailed, although much of it is based on work that has not yet been completed.

(2) Data from reconnaissance by Boucot, largely in 1954. In many areas for which no detailed information is available, the geology has been inferred from topographic and aeromagnetic trends, from a few collections of fossils, and from an evaluation of Hitchcock's geologic descriptions $(1861,1862)$. The text that follows summarizes the correlations. Although the senior author has obtained information from the sources indicated (index map), he is responsible for the interpretation herein.

Post-Devonian

Near Presque Isle, dikes of teschenite ( $t$ ) intrude sedimentary rocks of Late Silurian (early Ludlovian) age. There is no evidence for assigning a minimum age to these dikes, but the relatively fresh condition of the analcite in the teschenite suggests that the dikes postdate the Acadian orogeny. It is possible that the teschenites are similar in age to the "alkalic" rocks of the White Mountains plutonic-volcanic series, which Toulmin (1961, p. 775-779) considers to be about 185 million years old. Other occurrences of teschenite known in northern Maine (not shown on the map) are: Spencer Stream, Somerset County, where it cuts Seboomook Formation (Ds) (Lower Devonian, Oriskany); Granny's Cap, Somerset County, where it intrudes Lower Devonian rhyolite (Dv); and Chain Lakes, Franklin County, where it cuts Precambrian(?)gneiss (p€sg) (Boucot, Griffin, Denton, and Perry, 1959, p. 16-17).

A diabase dike (d) has been mapped near the east edge of the map area by D. M. Larrabee, U. S. Geological Survey, on the basis of aeromagnetic data and a few outcrops. It is likely that the dike is of Triassic age.

\section{Middle Devonian}

The youngest known stratified formation in northern Maine is the Mapleton Sandstone (Dm) (Williams and Gregory, 1900) of the Presque Isle region, Aroostook County. Fossiliferous cobbles of the Lower Devonian Chapman Sandstone (Williams and Gregory, 1900) have been found in the Mapleton Sandstone. Schopf (unpublished data) reports spores of probable
Middle Devonian age from the Mapleton Sandstone. Because it is poorly indurated and relatively undeformed, it is believed to be of post-Acadian (Late Devonian) age, resting unconformably on both Upper Silurian and Lower Devonian strata. Lithologically it is similar to the Upper Devonian Perry Formation (Smith and White, 1905) in southeastern Maine (Boucot, 1954 , p. 148 ) and to the Horton Group of Mississippian age (Bell, 1929) in Canada.

\section{Middle(?) Devonian}

Relatively fresh Middle(?) or Lower Devonian plutonic rocks of granitic or mafic composition are common. Most of the granitic intrusives (Dg) are light-colored medium- to coarse-grained granites and granodiorites; the mafic intrusives (Dd and Dga) include dark-colored diorite and gabbro in the southwestern part of the area. Conspicuous in northern Maine are the mountains underlain by contact-metamorphosed stratified rocks (hornfels), shown as stippled areas on the geologic map, that rim the areas occupied by these Devonian plutonic rocks.

\section{Lower Devonian}

All the stratified rocks older than the plutonic rocks described above are tightly folded. The folding is of Early or Middle Devonian age associated with the Acadian orogeny, of Early Silurian or latest Ordovician age associated with the Taconic orogeny, and also of pre-Ordovician age (Neuman, 1960).

Rocks of Schoharie age.-The youngest rocks (Dssc) predating the Middle(?) Devonian plutonic rocks in northern Maine include dark-colored sandstone and slate of the Tomhegan Formation in the upper part of the Moose River Group (Boucot, 1961) in Piscataquis and Somerset Counties, and possibly also siltstone and conglomerate northwest of Traveler Mountain in Piscataquis County. The Tomhegan Formation contains marine fossils of Schoharie age (zone of Amphigenia) (Boucot, 1961), whereas the siltstone and conglomerate have well-preserved plant remains of probable Early Devonian age (Rankin, 1958), and a few ostracodes of possible marine origin near the top of the section.

Beneath the strata of Schoharie age and the plant bearing beds correlated with them are discontinuous bodies of extrusive rhyolite and pyroclastic rocks of rhyolitic to dacitic composition (Dv). Intrusive rocks (Di) in the strata underlying the extrusives are of similar chemical composition and are concluded to be genetically associated with the extrusives. Datable fossils have not been obtained from these volcanic rocks, but their stratigraphic position either between strata of Oriskany and Schoharie age, or above strata of Oriskany age, places them all within the upper part of the Lower Devonian. 
Rocks of Oriskany age,-Diabase and greenstone of both extrusive and intrusive origin are associated with stratified rocks of Oriskany age but have not been observed associated with strata of Schoharie age. These mafic igneous rocks are not shown on the geologic map except for a large body of diabase, (Ddg), which is present north of Parlin Pond in Somerset County.

Dark-colored sandstone and slate (Dss) containing marine fossils of Oriskany age occur in four areas: in Somerset and Piscataquis Counties where they form the Tarratine Formation (Boucot, 1961) in the lower part of the Moose River Group; near Big Spencer Mountain in Piscataquis County; in the Telos LakeSoubunge Mountain area of Piscataquis County; and in the vicinity of Grand Lake in Penobscot County. The sandstone and slate are interpreted as being laterally discontinuous and derived from separate source areas.

Equivalent to the dark-colored sandstone and slate is the Seboomook Formation (Ds) (Boucot, 1961), the most widespread rock unit in northern Maine. The Seboomook is dark-colored cyclically layered slate, siltstone, and fine-grained sandstone that has yielded fossils of Oriskany age in five widely separated areas, as well as fossils of Helderberg age (Boucot, Harper, and Rhea, 1959) in its lower part in western Somerset County. Perkins (1925, p. 375) reported one occurrence of Monograptus in it, but this remains unverified. The great rarity of fossils in this unit accounts in part for the difficulty in determining its age span. In Somerset and Piscataquis Counties the Seboomook grades into fossiliferous sandstone (Dss) of Oriskany age. Near Little Big Wood Pond in Somerset County and at Lobster Lake in Piscataquis County it rests on strata of Late Silurian (early Ludlow) age (Ssl). In Penobscot and Aroostook Counties it rests on strata (DSls and $\mathrm{Su}$ ) that in some places contain Upper Silurian (early Ludlow) fossils, and in others, fossils of Helderberg age.

The dark-colored sandstone and associated greenstone (Dsg) of the Boundary Mountains in Somerset County belong to the Frontenac Formation of probable Early Devonian age. In the Attean quadrangle the Frontenac overlies the Seboomook Formation with gradational contact (A. L. Albee, oral communication, 1958; Marleau, 1957). However, in the Allagash Lake area of Piscataquis County, the Frontenac underlies the Seboomook Formation, suggesting an intertonguing relation between the two.

Rocks of Helderberg age. -In one area of Somerset County the Beck Pond Limestone (Boucot, Harper, and Rhea, 1959) (Dls), a unit of limestone and limestone conglomerate containing fossils of Helderberg age, occurs beneath the Seboomook Formation. In another area of Somerset County felsite and limestone (Parker Bog Formation, Boucot, 1961) of Helderberg age are interbedded.

In Aroostook County, in the Presque Isle area, White (1943) and Fletcher (oral communication, 1959) found fossils of Helderberg age in tuff which is part of the Hedgehog Trachyte of Gregory (1900), a unit of interlensing volcanic and sedimentary rocks (Dvg)
(Boucot and others, unpublished data). This unit (Dvg) is overlain conformably by the Edmunds Hill Andesite of Gregory (1900) (Da), the Chapman Sandstone (Dsc), and an unnamed slate (Dsl) (Boucot and others, unpublished data). The Edmunds Hill Andesite interfingers with the Chapman Sandstone which in turn appears to grade into the unnamed shale. The Chapman Sandstone is of Helderberg age (Williams and Gregory, 1900 ) and the lower part of the unnamed slate has recently been shown to be of the same age (Boucot and others, unpublished data). In the Presque Isle area units of Helderberg age overlie strata of early Ludlovian age (Boucot and others, unpublished data) with probable unconformity.

Red slate (Drs) interlayered with green slate, volcanic rocks, and quartzite (Whisky Quartzite and Capens Formation, Boucot, 1961), occurs in the southern part of the Moosehead Lake region of Somerset and Piscataquis Counties beneath the Seboomook Formation and above strata of Silurian or Devonian age (DSls). Red slate also occurs near Ripogenus Dam in Piscataquis County beneath the Seboomonk Formation and above greenstones of Silurian or Devonian age (DSv). Fossils of Helderberg age have been found in the southeast corner of the Pierce Pond quadrangle in rocks similar to the Capens Formation.

\section{Devonian or Silurian}

Extrusive and intrusive greenstone and diabase (DSv) near Ripogenus Dam are dated as Devonian or Silurian. They are underlain by calcareous rocks (Sls) with Lower Silurian fossils (Willard, 1945). Sills(?) of greenstone (DSv) occur in the Maple and Hovey Mountains area of Aroostook County (Pavlides, in press).

Calcareous slate, calcareous sandstone, limestone, limestone conglomerate, and tuffaceous sandstone of uncertain age (DSls) are exposed in a number of areas in Somerset, Piscataquis, Penobscot, and Aroostook Counties. Late Silurian (Ludlow) and Helderberg fossils have been obtained from these rocks in several places.

\section{Silurian}

Rocks containing Late Silurian (Ludlow) fossils have been found in several areas. In Somerset County such rocks include conglomerate, sandstone, and arkose (Scs) beneath strata of Oriskany age (Dss, Ds) and above rocks of Precambrian(?) (p€qm) to Late Silurian (Ssl) age. In Somerset and Piscataquis Counties there are limestone, calcareous sandstone, and slate (Ssl). In the Perham-Stockholm area of Aroostook County, conglomerate and sandstone (Scs) contain graptolites of early Ludlow age (Ruedemann, 1947, p. 75). Near Presque Isle a unit of calcareous sandstone and slate (Ssl) contains fossils, including Conchidium of Late Silurian (Ludlow) age. Pristiograptus and other graptolites from this unit (Ssl) have been dated as early Ludlovian (Berry, 1960).

The unit of undifferentiated Silurian rocks (Su) includes limestone, calcareous slate, and calcareous sandstone, locally with some tuff and conglomerate, in widely scattered occurrences. Fossils of Silurian age occur within this unit, but it has not been studied in enough detail to allow subdivision. 
In Aroostook County, Pavlides (in press) has mapped a slate unit (Ssm) that encloses thin, lenticular manganiferous strata containing Lower Silurian fossils. Rocks below this unit are tentatively assigned a Silurian(?) age, but confirmatory paleontologic evidence is not available. Felsite and local volcanic breccia (Svf) and green slate and graywacke (Ssg) with lenses of metaperlite (Svp) are included in this category. Recent mapping in this area suggests that some qi these rocks may be older than Silurian and some may be younger (L. Pavlides, oral communication, 1|961).

At three localities fossiliferous calcareous units have been mapped which contain a late Llandoverian or Wenlockian fauna. These localities are: east of Kennebago Lake on the west side of Blanchard Pond, Franklin County (R. J. Willard, oral communication, 1958); on Limestone Hill immediately west of Flagstaff Mountain, Somerset County; and at Ripogenus Dam, Piscataquis County (Willard, 1945). Conglomer ates with late Llandovery fossils, and limestone with probable Wenlock-age fossils are here included in a single unit (Ssc), in a belt between the East Branch of the Penobscot River and Marble Pond (Penobscot County).

\section{Silurian or Ordovician}

A variety of felsic and mafic volcanic rocks (SOv) occur in several places in northern Maine between rocks of Silurian and Devonian age and rocks of probable pre-Silurian age. Fossils are almost unknown in these volcanic rocks, and little study has been devoted to the volcanic rocks. It is probable that volcanics of both Silurian and Ordovician age have been lumped together in this unit.

\section{Ordovician}

South of Ripogenus Dam in Piscataquis County pre-Silurian gabbro (Oga) intrudes sedimentary rocks (Es) that have been folded by a pre-Silurian orogeny.

Other mafic intrusive rocks of probable Ordovician age include diorite (Od), gabbro (Oga), and serpentine (Os) which intrude Cambrian or Ordovician undifferentiated sedimentary rocks in Franklin and Somerset Counties (Hurley and Thompson, 1950; Wing and Dawson, 1949). An altered granitic intrusive $(\mathrm{Og})$ is associated with Ordovician volcanic rocks (Ovm) in northeastern Penobscot County and adjacent Aroostook County.

West of Presyue Isle, calcareous sandstone and siltstone (Osc) contain trilobites which $\mathrm{H}$. B. Whittington (oral communication, 1960) considers to be of Ashgillian age (uppermost Ordovician). This unit is underlain by dark-colored sandstone, black shale, and chert (Oss) which are of Middle Ordovician age (Miller, 1947; Boucot and others, unpublished data). A single slate outcrop (Osg) of Ashgillian age is present just east of Pond Pitch on the East Branch of the Penobscot River. Much of eastern Aroostook County is underlain by platy limestone (Ols), the Aroostook Limestone (of earlier reports). White (1943) mapped this unit as Silurian, but fossils now show that it may be of Middle Ordovician (Caradocian) age (Pavlides and others, 1961).
Rhyolitic tuff (Ot) (the Kennebec Formation, Boucot, 1961) containing Middle Ordovician fossils occurs a few miles west of Moosehead Lake in Somerset County. A similar unit extends more than 20 miles northeast from Chamberlain Lake in Piscataquis County but fossils have not been discovered in it (B. A. Hall, oral communication, 1960). South of Grand Lake in the valley of the East Branch of the Penobscot River an assemblage of greenstone flows and tuffs (Ovm), considered by Boucot to be of Early Ordovician age, occurs beneath Silurian and Ordovician rocks (Ssc and Osg). The tuffs contain brachiopods on nearby Sugarloaf Mountain (Neuman, 1960). Middle Ordovician graptolites are in dark slate and bedded chert (Oss) that probably lie immediately above the greenstones along Wassataquoik Stream (Dodge, 1881; Ruedemann and Smith, 1935).

\section{Ordovician or Cambrian}

Beneath the Devonian and Silurian rocks in parts of northern Maine is a complex of undifferentiated sedimentary rocks (O€u), felsic volcanic rocks (O€vf), and mafic volcanic rocks (OEvm), which is thought to be of Cambrian or Ordovician age. In general, these rocks are more phyllitic than the overlying Silurian strata, and where mapped in detail show field relations that suggest a major regional unconformity corresponding to the Taconic orogeny. No fossils have been found in these rocks, but they are closely associated with the Middle Ordovician tuff $(\mathrm{Ot})$ in Somerset County and are lithologically similar to the fossiliferous pre-Silurian rocks in Penobscot and Aroostook Counties.

\section{Cambrian(?)}

Interbedded quartzite and slate (Grand Falls For mation of Ruedemann and Smith, 1935) (Es) underlies with probable angular unconformity the Ordovician greenstone and tuff (Ovm) of the East Branch of the Penobscot River. This unit ( $\epsilon s)$ may be of Cambrian age because of its stratigraphic position and the presence of Oldhamia (Neuman, 1960). Similar rocks are found south of Chesuncook Lake. Twelve miles east of Churchill Lake is a small area of dark-gray slates and phyllites which lie unconformably beneath fossiliferous Ordovician rocks (B. A. Hall, oral communication, 1960). This unit is also assigned a Cambrian(?) age.

\section{Cambrian, Ordovician, Silurian, or Devonian}

Much of the area in the southern and eastern parts of the map is underlain by sedimentary rocks (DEus) and some volcanic rocks (DEUv) whose age and stratigraphic relations are very poorly understood. The only known fossils from this map unit are favositid corals and pelmatozoan debris from limestone at Moro in Aroostook County.

\section{Precambrian(?)}

In western Somerset and Franklin Counties a basement complex characterized chiefly by schist and gneiss (p€sg) is overlain by Silurian and Lower Devonian strata. At Jim Pond in Franklin County, gneiss (p€sg) is overlain to the southeast by Upper Silurian strata (Ssl). The Silurian beds in turn abut pre-Silurian rocks (OEu) to the southeast, at a dis- 
tance of several hundred yards from the gneiss. The close association of the pre-Silurian gneiss with the less metamorphosed pre-Silurian slate, phyllite, and volcanics suggests that the gneiss is distinctly older and may be Precambrian in age.

\section{AEROMAGNETIC DATA}

By

John W. Allingham

\section{Introduction}

About 12,000 square miles of northern Maine was aeromagnetically surveyed between 1950 and 1959 by four organizations: U. S. Geological Survey; Bear Creek Mining Company; Aero Service Corporation; and the Maine Geological Survey (see index map). The U. S. Geological Survey and the Bear Creek Mining Company used 1/4-mile and 1/2-mile spacing between flight lines and an altitude of about 500 feet above the ground. The Maine Geological Survey used one-mile spacing and an altitude of 1,000 feet; and the Aero Service Corporation used two-mile spacing and an altitude of 1,000 feet. The wider spacing and higher flight altitude produce a smoother magnetic pattern. All of the surveys measured total magnetic intensity.

The present project was proposed by W. J. Dempsey in 1955. The Maine Geolosical Survey provided financial support for preparation of the magnetic data. Aero Service Corporation and Bear Creek Mining Company furnished unpublished aeromagnetic maps for a part of the area; their cooperation is gratefully acknowlédged. J. R. Kirby, B. L. Bennett, and B. L. White of the U. S. Geological Survey compiled the composite aeromagnetic map to an arbitrary datum. Aeromagnetic maps of larger scale have been published or placed in open file by the U. S. Geological Survey for most of the area. Absence of magnetic data over Mt. Katahdin and Turner Mountain is due to rugged topography.

Magnetic anomalies are produced by a combination of two magnetizations, one induced in the rocks by the magnetic field of the earth, and the other natural or remanent. The relationships of magnetic and geologic features, however, are reported without regard to the type of magnetization. Most of the magnetic anomalies in the area are caused by changes in content of accessory magnetite disseminated throughout large volumes of bedrock. The presence of other minerals that are only slightly magnetic, such as pyrrhotite, ilmenite, and hematite, also contributes to the magnetic properties of the rock. The size and shape of a magnetic rock unit also affect the associated anomaly. Interbedded tabular volcanic rock units in this area dip steeply enough to produce linear magnetic anomalies. Small plutons are commonly elliptical or rounded and produce anomalies of similar shape.

The aeromagnetic map is used as an aid in tracing magnetic rock units and defining their boundaries in areas where geologic information is sparse. In northern Maine, small, sharp magnetic anomalies are directly related to near-surface or exposed magnetic rock. Broad magnetic anomalies over downfolded sedimentary, rocks are interpreted as being caused by the deeply buried crystalline floor of the basins. The aeromagnetic patterns have a general northeasterly trend in conformity with strikes of the stratified rock, mafic intrusions, and pyrrhotite- or magnetite-bearing slate.

\section{Anomalies associated with intrusive rocks}

Many intrusive rocks in northern Maine produce characteristic magnetic anomalies; for example, felsic rocks are typically associated with anomalies of low gradient. Magnetically flat areas are associated with granitic rock $(\mathrm{Dg})$, such as at Bald Mountain ( $501 \mathrm{~N}$, $\left.{ }_{4 \mathrm{E}}^{4}\right) \mathrm{l}$ /. or with monzonite $(\mathrm{Og})$, such as the pluton near Rockabema Lake ( $511 \mathrm{~N}$., $55 \mathrm{E})$. Magnetic lows are associated with the centers of some intrusions having small marginal diorite bodies, such as the quartz monzonite (p€qm) west of Attean pond $\left({ }^{50} 5 \mathrm{~N} .,{ }^{4} 0 \mathrm{E}\right.$.) (Albee, 1960, written communication). The low is produced by the magnetic contrast between the quartz monzonite, its inclusions, and the adjacent diorite and granulite. Magnetic highs adjacent to other intrusions, such as the Onawa pluton (503N., 47E.), are the result of marginal mafic rocks, mainly intrusive diorite or dioritic differentiates.

Magnetic anomalies are commonly assuciated with hornfels rims of intrusive bodies where the magnetite content of the intruded sedimentary rocks is increased by metasomatic replacement or by oxidation of iron sulfide. The granite pluton at Meduxnekeag Lake ( $51_{\mathrm{ON}} ., 57 \mathrm{E}$.), for example, is surrounded by magnetic highs, which are related to magnetite and pyrrhotite-rich hornfels borders.

Some granitic stocks have internal magnetic zoning that suggests a lithologic zoning. The quartz monzonite intrusion (Dg) near Jackman ( $505 \mathrm{~N}^{2},{ }^{4} 0 \mathrm{E}$.) has an outer zone that is more magnetic than its core, suggesting a different border phase of the quartz monzonite. Similarly the granitic stock (Dg) at Chandler Mountain ( 515 N., 52 E.) also is magnetically zoned (Allingham, 1961); the anomaly resembles anomalies observed over ring-dike structures. The intrusion at Arnold Pond ( 503 N., $36 \mathrm{E}$.) has a magnetic core and an outer zone marked by magnetic lows. This pluton is rimmed by a few magnetic highs, which indicate mag-

$1 /$ Geographic locations are indicated by standard Army Map Service coordinates on the margin of the map. 
netic hornfels. Other granitic intrusions $(\mathrm{Dg})$ in this area show only the flat pattern that is characteristic of the regional magnetic gradient.

Magnetic patterns delineate elongate diorite masses in the Katahdin batholith. Aeromagnetic contours outline one intrusion (Dd) near Holbrook Pond ( $508 \mathrm{~N}$., 49E.) and the northwest alinement of a similar magnetic pattern suggests the presence of another mafic body at Trout Mountain (507N., 51E.). This linear feature continues as a fault at the northwest border of the batholith. The subsurface contacts between the diorite and the granite near Holbrook Pond were estimated from magnetic data to dip northeasterly and southwesterly about $55^{\circ}$ (Allingham, 1960).

Magnetic highs are commonly associated with diorite or gabbro intrusives. Contrasting rock types such as diorite and quartz monzonite northwest of the Moose River synclinorium can be distinguished by associated magnetic patterns. Some of the highamplitude magnetic anomalies at the west border of the quartz monzonite (p€qm), for example the 1200gamma anomaly near Whipple Pond ( $504 \mathrm{~N} ., 39 \mathrm{E}$.$) ,$ are associated with diorite. Analysis of these magnetic anomalies indicated steep or nearly vertical contacts.

Anomalies of intermediate amplitude are associated with the gabbro (Dga) near the south end of Moosehead Lake ( $504 \mathrm{~N}$., $45 \mathrm{E}$.). The magnetic patterns outline the gabbro underlying the lake and show its extension eastward toward Big Shanty Mountain ( $504 \mathrm{~N}$., $48 \mathrm{E}$.). On the basis of magnetic information the gabbro is believed to extend eastward, at depth, to Little Shanty Mountain, and from there southward to the gabbro at Katahdin Iron Works (503N., 48E.), where magnetic patterns show a more extensive subsurface mafic body. Southwest of Moosehead Lake, near Moxie Pond ( $502 \mathrm{~N}$., 43E.), the anomaly associated with the gabbro is small but is paralleled by a linear magnetic feature of higher amplitude, believed to be caused by diabase, probably an offshoot of the gabbro, or by a magnetite-bearing slate. Interpretation of magnetic information indicates that this feature dips southward about $60^{\circ}$.

A heterogeneous pattern of sharp magnetic highs and lows is commonly associated with mafic intrusions, such as observed over the gabbro (Oga) at Bean Brook, west of Mt. Katahdin ( ${ }^{50} 7 \mathrm{~N}$., ${ }^{4} 8 \mathrm{E}$.). In addition, some gabbro bodies have high-amplitude anomalies associated with their outer margins. These magnetic highs are due to more magnetic zones within the gabbro and to marginal hornfels. This feature is particularly noticeable over the gabbro at Dimmick Mountain ( 501 N., $43 \mathrm{E}$.).

Southwest of the Moose River synclinorium the area is magnetically complex, owing partly to the closer spacing of flight lines and the lower altitude of the aircraft and partly to the complexity of the bedrock geology.

A diabase dike, 100 to 200 feet wide, has been traced southwestward from an outcrop at East Grand Lake for more than 25 miles across the Danforth area $(509 \mathrm{~N} ., 60 \mathrm{E}$.) by a distinctive linedr aeromagnetic pattern. From the magnetic anomaly the presence of this dike was inferred for an additional 35 miles to diabase exposed southwest of Milo ( $501 N ., 49-50 E$.).

Anomalies associated with volcanic rocks

The aeromagnetic pattern over the slate belt north of Moosehead Lake, near Allagash Lake (513N., 46E.), for example, outlines a small anticlinorium and shows its northeasterly trend. The anomalies over this anticlinal structure and at Canada Falls Deadwater ( $508 \mathrm{~N}_{\text {. }}, 41 \mathrm{E}$.) are caused by altered basalt and gabbro associated with argillaceous sandstone (Dag).

North of Mt. Katahdin, magnetic trends associated with mafic volcanic rocks outline a large southwestward-plunging anticlinorium having a core of preSilurian sedimentary rocks $(510 \mathrm{~N}$., $46 \mathrm{E}$. to $52 \mathrm{ON}$., $54 \mathrm{E}$.). These distinctive magnetic patterns are useful for correlation of the volcanic units where they are concealed between areas of exposed rock.

A linear magnetic anomaly extending from Presque Isle Stream in Aroostook County $\left(5 \mathrm{I}_{5 \mathrm{~N}}\right.$., $57 \mathrm{E}$.) to Otter Pond suggests the presence of a continuous unit, probably volcanic rocks or magnetite-bearing slate, in this little-known area. South of this linear anomaly, near Howe Brook, isolated volcanic rocks (DSv and DEuv), probably basaltic flows, produce complex magnetic patterns that resemble those over some gabbro bodies. These small magnetic anomalies continue southwestward toward the anomalies over the $\mathrm{Mt}$. Chase volcanic sequence ( $5 \mathrm{l}_{1 \mathrm{~N}}$., $54 \mathrm{E}$.) and form a broad, open $\mathrm{S}$-shaped pattern that may be correlated with a stratigraphic unit and with a corresponding $\mathrm{S}$-shaped geologic structure.

Linear magnetic anomalies $(500 \mathrm{~N}$., $38 \mathrm{E}$. to $508 \mathrm{~N}$, ${ }^{4} 6 \mathrm{E}$.) that form a belt on the south flank of the Moose River synclinorium are caused by elongate tabular bodies of volcanic rocks and near-surface mafic intrusions striking about N. $60^{\circ} \mathrm{E}$. and dipping southward from $15^{\circ}$ to nearly $90^{\circ}$.

\section{Anomalies associated with sedimentary rocks}

Some magnetic highs are directly related to sedimentary rocks of appreciable susceptibility. A belt of magnetic anomalies south of Moosehead Lake near Bingham (499N., 43E.) is associated with a sedimentary sequence (OEu) that is mainly gray slate containing pyrrhotite, pyrite, or magnetite. These anomalies not only show a structural trend but also suggest a synclinal fold within a larger anticline, according to dips interpreted from the magnetic data (Allingham, 1960). Near Smyrna Mills (511N., 57E.), magnetiterich and pyrrhotite-rich slate produce broad arcuate magnetic anomalies part-way around the north side of two granite plutons. These anomalies are partly parallel to the trend of anomalies associated with volcanic rocks at $\mathrm{Mt}$. Chase to the west and near Howe Brook to the north. The anomalies associated with coalesced hornfels rims suggest several adjoining intrusions.

Many sedimentary rocks, such as those compris ing manganiferous iron formations, although not of ore grade, contain disseminated iron oxides in amounts sufficient to produce substantial magnetic anomalies where these rocks have been metamorphosed (Pavlides, in press). 


\section{Anomalies associated with rocks underlying sedimentary basins}

A northeast-trending magnetic high outlines the Moose River synclinorium ( $501 \mathrm{~N}$., $38 \mathrm{E}$. to $508 \mathrm{~N}$., $45 \mathrm{E}$.). Hurley and Thompson (1950) correlated the exposed igneous rocks in the synclinorium with aeromagnetic anomalies. The magnetic contrast between felsic volcanic and intrusive rocks (Dv, Di) near the synclinorial axis and the relatively nonmagnetic sandstone and slate (Dss, Ds) on the flanks of the synclinorium, however, is not large enough to contribute significantly to the broad observed anomaly. A minimum depth of about 2 miles to magnetic rocks was determined from aeromagnetic profiles, using the method of Vacquier and others (1951). Geologic features indicate that this depth is too low. The broad anomaly is probably caused by mafic basement or Devonian gabbro intruding the synclinorium at depth. From the depth of burial and from the amplitude and shape of the anomaly the rocks are estimated to have a magnetic susceptibility of 1.5 to $2.0 \times 10^{-3}$ cgs units. This susceptibility indicates a gabbroic or dioritic rock unit. The mass causing the anomaly is 5 miles wide and about $31 / 2$ miles thick, and is inclined $30^{\circ}$ to $40^{\circ} \mathrm{N}$. The association of broad magnetic highs over synclines has been observed elsewhere by Grantz and Zietz (1960). A similar high associated with a broad synclinorium that trends northeast parallel to the St. John and Allagash Rivers ( $515 \mathrm{~N}$., 43E. to $520 \mathrm{~N} ., 47 \mathrm{E}$.) is shown by aeromagnetic profiles over relatively nonmagnetic slate of Devonian age.

\section{References cited}

Albee, A. L., 1961, Boundary mountain anticlinorium, west-central Maine and northern New Hampshire Art. 168, in U. S. Geol. Survey Prof. Paper 424-C, p. C51-C54.

Allingham, J. W., 1960, Use of aeromagnetic data to determine geologic structure in northern Maine: Art. 54, in U. S. Geol. Survey Prof. Paper 400-B, p. B117- $\overline{\mathrm{B}} 119$.

1961, Aeromagnetic interpretation of zoned intrusions in northern Maine: Art. 387, in U. S. Geological Survey Prof. Paper 424-D, p. D265-D266.

Bell, W. A., 1929, The Horton-Windsor District, Nova Scotia: Geol. Survey of Canada Mem. 155.

Balsley, J. R., Jr., and Kaiser, E. P., 1954, Aeromagnetic "survey and geologic reconnaissance of part of Piscataquis County, Maine: U. S. Geol. Survey Geophys. Inv. Map GP-116.

Berry, W. B. N., 1960, Early Ludlow graptolites from the Ashland area, Maine: Jour. Paleontology, v. 34, p. 1158-1163.

Boucot, A. J., 1954, Age of the Katahdin granite: Am. Jour. Sci., v. 252, p. 144-148.

1961, Stratigraphy of the Moose River synclinorium, Maine: U. S. Geol. Survey Bull. $1111-E$, p. $153-188$.

Boucot, A. J., Griffin, J. R., Denton, G. H., Perry, P. S., 1959, The geology of a six mile section along Spencer Stream, Somerset County, Maine: Maine Geol. Survey, Spec. Geol. Studies Ser. No. $2,26 \mathrm{p}$.
Boucot, A. J., Harper, C., and Rhea, K., 1959, Geology of the Beck Pond area, Township 3- Range 5,

Somerset County, Maine: Maine Geol. Survey, Spec. Geol. Studies Ser. No. 1, 33 p.

Dodge, W. W., 1881, Lower Silurian fossils in northern Maine: Am. Jour. Sci., 3d ser., v. 22, p. 434-436.

Doyle, R. G., Young, R. S., and Wing, L. A., 1961, A detailed economic investigation of aeromagnetic anomalies in eastern Penobscot County, Maine: Maine Geol. Survey, Spec. Econ. Studies Ser. no. $1,69 \mathrm{p}$.

Grantz, Arthur, and Zietz, Isidore, 1960, Possible significance of broad magnetic highs over belts of moderately deformed sedimentary rocks in Alaska and California: Art. 158 in U. S. Geol. Survey Prof. Paper 400-B, p. B342-B347.

Hitchcock, C. H., 1861, General report upon the geology of Maine: Maine Board Agriculture, 6th Ann. Rept.

1862, Geology of Maine: Maine Board Agriculture, 7 th Ann. Rept.

Hurley, P. M., and Thompson, J. B., Jr., 1950, Airborne magnetometer and geological reconnais sance survey in northwestern Maine: Geol. Soc. America Bull., v. 61, p. 835-841.

Keith, A., 1933, Preliminary geologic map of Maine: Maine Geol. Survey.

Marleau, R., 1957, Preliminary report on Woburn area, Quebec: Quebec Dept. Mines Prelim. Rept. no. 336.

Miller, R. L., 1945, Geology of the Katahdin pyrrhotite deposit and vicinity, Piscataquis County, Maine: Maine Geol. Survey Bull. 2, 21 p.

1947, Manganese deposits of Aroostook County, Maine: Maine Geol. Survey Bull. 4, 77 p.

Neuman, R. B., 1960, Pre-Silurian stratigraphy in the Shin Pond and Stacyville quadrangles, Maine: Art. 74 in U. S. Geol. Survey Prof. Paper 400-B, p. $\mathrm{B} 16 \overline{6}-\mathrm{B} 168$

Pavlides, Louis, 1962, Geology and manganese deposits of the Maple and Hovey Mountains area, Aroostook County, Maine: U. S. Geol. Survey Prof. Paper 362 (in press).

Pavlides, Louis, Neuman, R. B., and Berry, W. B. N. 1961, Age of the "ribbon rock" of Aroostook County, Maine: Art. 30 in U.S. Geol. Survey Prof. Paper 424-B, p. B65-B $\overline{67}$.

Perkins, E. H., 1925, Contributions to the geology of Maine, no. 2, pt. 1, The Moose River sandstone and its associated formations: Am. Jour. Sci., 5th ser., v. 10, p. 368-375.

Philbrick, Shailer S., 1936a, The contact metamor phism of the Onawa pluton, Piscataquis County, Maine: Am. Jour. Sci., 5th ser., v. 31, no. 181, p. 1-40.

1936b, The geology of the Appalachian Trail in Maine, in Guide to the Appalachian Trail in Maine: The Appalachian Trail Conference, Washington, D. C., p. 197-215. 
Rankin, D. W., 1958, Lower Devonian nonmarine sediments in the vicinity of Traveler Mountain, NorthCentral Maine (abs.): Geol. Soc. America Bull., v. 69 , p. 1632 .

Ruedemann, Rudolf, 1947, Graptolites of North America: Geol. Soc. America Mem. 19, 652 p.

Ruedemann, Rudolf, and Smith, E. S. C., 1935, The Ordovician in Maine: Am. Jour. Sci., 5th ser., v. 30 , no. 178 , p. 353-355.

Smith, G. O., and White, C. D., 1905, The geology of the Perry Basin in southeastern Maine: U.S. Geol. Survey Prof. Paper 35, 107 p.

Toulmin, Priestley, 1961, Geological significance of lead-alpha and isotopic age determinations of "alkalic" rocks of New England: Geol. Soc. America Bull., v. 72, p. 775-779.

Vacquier, Victor, Steenland, N. C., Henderson, R. G., and Zietz, Isidore, 1951, Interpretation of aeromagnetic maps: Geol. Soc. America Mem. 47, $151 \mathrm{p}$.
White, W. S., Cloud, P. E., and Bridge, J., 1943, Occurrences of manganese in eastern Aroostook County, Maine: U. S. Geol. Survey Bull. 940-E, p. 125-161.

Willard, Bradford, 1945, Silurian fossils from Ripogenus Dam, Maine: Jour. Paleontology, v. 19, p. 64-68.

Williams, H. S., and Gregory, H., 1900, Contributions to the geology of Maine: U. S. Geol. Survey Bull. $165,212 \mathrm{p}$.

Wing, L. A., and Dawson, A. S., 1949, Preliminary report on asbestos and associated rocks of northwestern Maine: in Report of the State Geologist, 1947-1948, Augusta, Maine, p. 30-62.

Wing, L. A., 1959, An aeromagnetic and geologic reconnaissance survey of portions of Penobscot, Piscataquis and Aroostook Counties, Maine: Maine Geol. Survey GP. and G. Survey no. 4, 7 p. 